\title{
Harpacticoida (Crustacea, Copepoda) from subterranean waters of Bue Marino cave, Sardinia, and St. Barthélémy cave, Corsica, and description of three new species *
}

\author{
Vezio Cottarelli ** and Maria Cristina Bruno **
}

\section{SUMMARY}

Three new species of harpacticoid copepods are described and discussed. Nitocrella beatricis $\mathrm{n}$. sp. has been collected in different hyporheic sites in Sardinia and in two caves ("Bue Marino" cave in Sardinia and "St. Barthélémy" cave in Corsica); Elaphoidella janas n. sp. and Parastenocaris triphyda n. sp. have been collected only in "Bue Marino" cave. Some considerations concerning the ecology and biogeography of the three species are also presented.

\section{INTRODUCTION}

During a faunistic research carried out in 1992, the impressive karstic system of "Bue Marino» cave (12 SA/NU, Dorgali, Cala Gonone) and the small "St. Barthélémy» cave, near Bonifacio town, Corsica, were explored. In these caves some samples of phreatic fauna, containing several rare or undescribed stygobiont harpacticoid copepods, were collected (1). In this paper the results of the research concerning the material collected in these caves and during other expeditions in Sardinia are explained and discussed.

* Research supported by grants from M.U.R.S.T. (60\%) and C.N.R.

** Dipartimento di Scienze Ambientali, Università della Tuscia. Via C. de Lellis, 01100, Viterbo.

1) All the material listed in this paper has been collected using the KaramanChappuis method and a particular hand-pump (Vigna Taglianti et al., 1969). 
Fam. AMEIRIDAE Monard, 1927; Lang, 1948

Gen. Nitocrella Chappuis, 1923

Nitocrella beatricis n. sp.

\section{Material}

33 ㅇ, 18 of, R. Argano, V. Cottarelli legg., 21.VI.1970, in the hyporheic water bed of Liscia river (Sassari province), at about 200 $\mathrm{m}$ from the bridge where the trunk-road N. 133 crosses the river. 8 우, 6 \& 8 , V. Cottarelli, B. Deriu legg., 14.V.1978, in the hyporheic water bed of Cedrino river (Nuoro province), near the bridge where the trunk-road N. 125, km 224.8, crosses the river. 9 of 9 , 7 \& , V. Cottarelli leg., 6.V.1984, in the hyporheic water bed of Quirra river (Cagliari province), near the trunk-road N. 125, km 83,8. 3 \%, , V. Cottarelli leg., in the hyporheic water bed of the Cannas river (Cagliari province), near the trunk-road N. 125, km 29,0. 5 우, 3 \& 8 , M. Cobolli, V. Cottarelli, E. De Matthaeis legg., 1.VI.1992, «Bue Marino» cave (Nuoro Province), inside the sandy-shore of the first freshwater lake in the southern drift of the cave, at about $600 \mathrm{~m}$ from the entry. 6 o $\circ, 2$ of \&, M. Cobolli, V. Cottarelli, E. De Matthaeis legg, 3.VI.1992, "St. Barthélémy» cave (Bonifacio, Corsica), in the sandy-shore of a little freshwater basin formed by the spring gushing from the bottom of the cave.

\section{Types}

Holotype: a female from Liscia river, completely dissected and mounted on a slide labelled $N$. beatricis ht. Paratypes: $20 \%+$ and 15 of o ( 25 dissected), mounted on slides labelled $N$. beatricis pt. with the indication of the collecting place, numbered from 1 to 35 . The material of the typical series, as well as all the other Nitocrella preserved in alcohol, are temporarily deposited at the "Dipartimento di Scienze Ambientali, Università della Tuscia», Viterbo (Cottarelli collection).

\section{Diagnosis}

A Nitocrella of the vasconica group Petkovski, 1976, characterized by the combination of the following features: first segment of the P2 - P4 endopods unarmed; second article with one, two, one setae, respectively; P5 baseoendopod with three inner setae; P5 exopod with four setae; distal margin of the anal operculum with a row of spinules. 
Description of the holotype

Body elongated, subcylindrical, without eyes or pigment; length, from the rostrum to the apex of the furcal rami, $0.678 \mathrm{~mm}$. Thoracic somites without ornamentation; first and second abdominal somite merged. Each abdominal segments with a posterior row of small hairy spinules; anal somite (Fig. 1) with a dorsal row of spines in the central share and a second row of larger spines surrounding the somite. Anal operculum (Fig. 1) convex, with five strong spines aligned along the margin. Furcal rami (Fig. 1): sub conical, short; the outer margin with a spine at about $2 / 3$ of the lenght; dorsal margin with a long outer seta and a spiniform inner seta; four setae apically inserted; the medial distal seta is the longest and it is of different size, the inner one is about twice as much the length of the outer one; at the basis of the principal apical seta there are three spinules.

Rostrum very small. Antennule (Fig. 4): eight-segmented: aesthete on fourth segment a little longer than the tip of the distal segment.

Antenna (Fig. 5): exopod one-segmented, armed with three distal setae, the inner one is the longest.

Mandible (Fig. 6): praecoxa with a bi-dentate pars incisiva; twosegmented palp: the second article with five distal setae.

Maxillule (Fig. 8): arthrite of the praecoxa with four distal spines; coxa with two setae; basipod with two distal and a lateral seta.

Maxilla (Fig. 7): syncoxa with an endite bringing three apical setae; endopod reduced to a tubercle with two setae.

Maxilliped (Fig. 9): shown in figure.

P1 (Fig. 12): three-segmented exopod, long as much as the first two segments of the corresponding endopod; all the segments of the exopod with one seta on the distal outer corner; third segment with three strong apical setae, the outer one is the shortest. Endopod three-segmented, the first one is the biggest and has a long seta at about 3/4 of the inner lateral margin. Distal segment with two long apical setae, the longest one geniculated, and with a little spine.

P2 (Fig. 13): second segment of the exopod with one seta on the inner distal corner; third segment with four apical setae. Second segment of the endopod with only one long distal seta; the endopod is shorter than the first two segments of the corresponding exopod.

P3 (Fig. 14): exopod as in P2; second segment of the endopod 


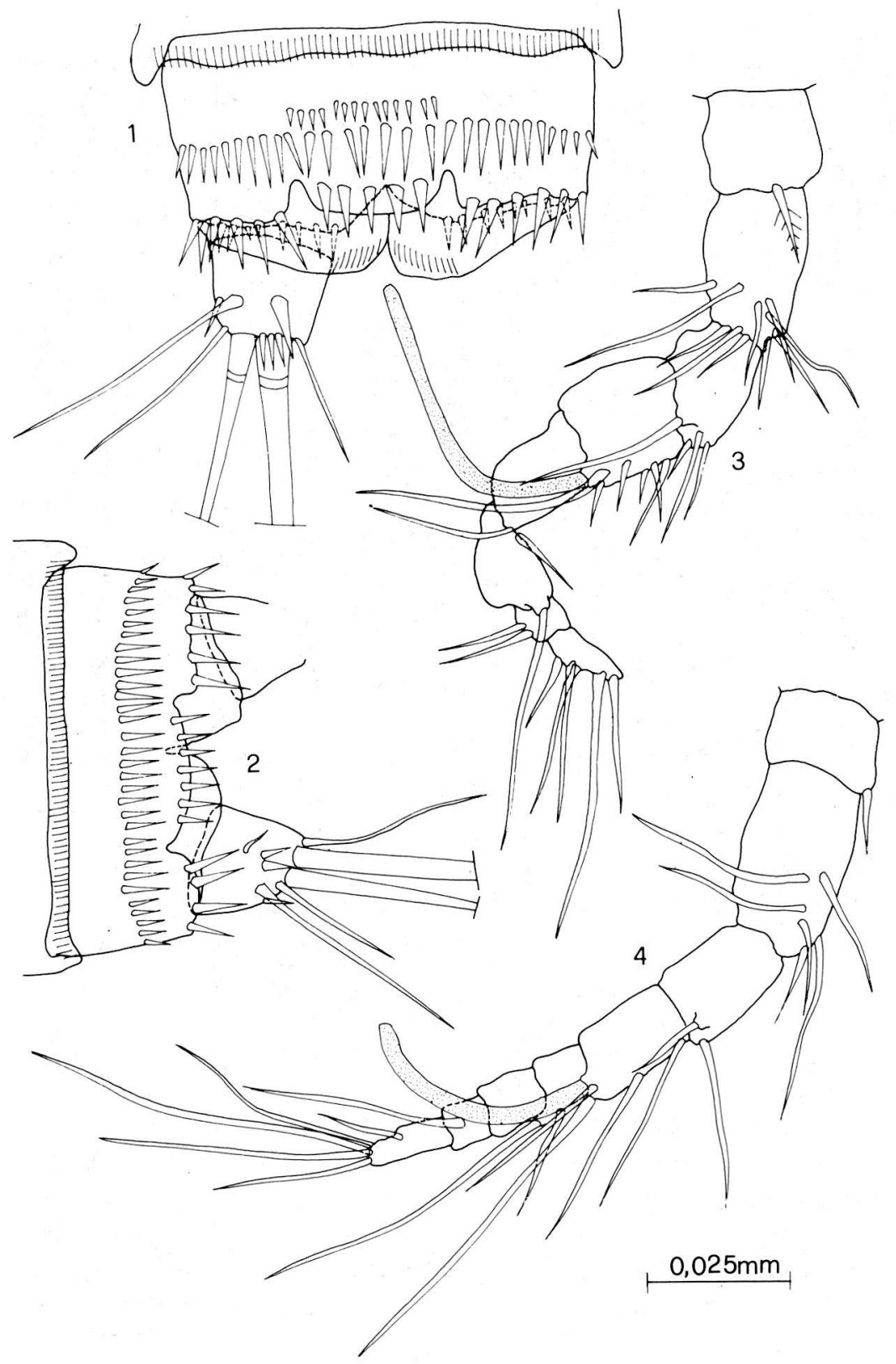

Figs. 1-4 - Nitocrella beatricis n. sp. 1,4: holotype $\$$; 2,3: paratype $\delta .1$, last somite, anal operculum and caudal ramus, dorsal view; 2 , last somite, anal operculum and caudal ramus, dorsal view; 3 , antennule; 4 , antennule. 


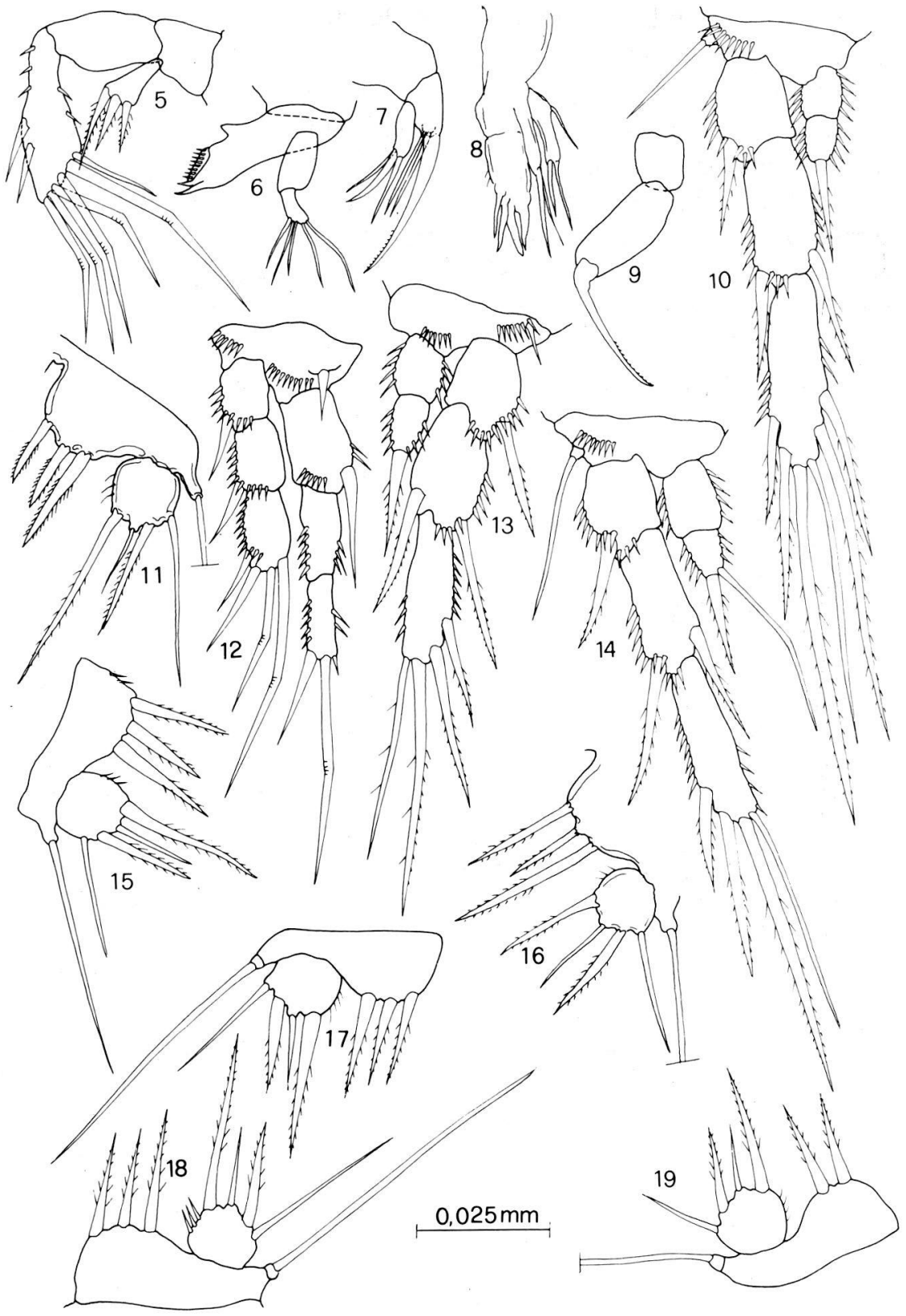

Figs. 5-19-Nitocrella beatricis n. sp. 5,6,7,8,9,10,12,13,14,18: holotype + . 5, antenna; 6, mandible; 7, maxilla; 8 , maxillule; 9, maxilliped; 10, P4; 11, P5 \& (Bue Marino Cave); 12, P1; 13, P2; 14, P3; 15, P5 \& (Cedrino River); 16, P5 \& (St. Barthélémy Cave); 17, P5 क (Quirra River); 18, P5; 19, P5 \& (Concas River). 
short, with a slender, curved seta on the distal inner corner, and a spinulate apical seta.

P4 (Fig. 10): third segment of the exopod with six setae. The endopod is a little longer than the first segment of the corresponding exopod. Second segment with a spinulate seta.

P5 (Fig. 18): baseoendopod with a long seta on the distal outer corner. The internal lobe with three setae. Exopod rounded, with one long and slender seta on the distal outer corner, three apical setae, the medium one is the shortest, and some spinules on the inner margin.

The setal formula of legs from 1 to 4 is listed below:

\begin{tabular}{lllllll} 
& \multicolumn{3}{c}{ Exopod } & \multicolumn{3}{c}{ Endopod } \\
P1 & 0 & 0 & $1,2,1$ & 1 & 0 & $0,2,0$ \\
P2 & 0 & 1 & $0,2,2$ & - & 0 & $0,1,0$ \\
P3 & 0 & 1 & $0,2,2$ & - & 0 & $1,1,0$ \\
P4 & 0 & 1 & $2,2,2$ & - & 0 & $0,1,0$
\end{tabular}

Description of the male

Length, measured as in the female: $0.650 \mathrm{~mm}$. Morphology and ornamentation of the anal operculum and furcal rami with little differences from the female's ones, as shown in figure 2. Antennule (Fig. 3): eight-segmented, the fourth and the fifth one strongly enlarged. Antenna, mouth parts, maxillipeds, legs P2-P4 (Figs. 21, 22, 23) as in the female.

P1 (Fig. 20): as in the female but the inner spine of the baseoendopod is transformed as is usual in the genus.

P5 (Fig. 25): baseoendopod less developed than in the female, with only two setae on the inner lobe; exopod rounded with four setae, the inner one is the longest.

P6 (Fig. 26): reduced to a little plate with two distal setae.

\section{Variability}

A female collected in Rio Concas with two inner setae on P5 baseoendopod (Fig. 19) instead of three; the number of spines on the anal operculum varies between five and seven. The other features considered are constant in all the specimens. Figures 11, 15, 16, 17 illustrate the P5 of specimens from different sampling sytes. 


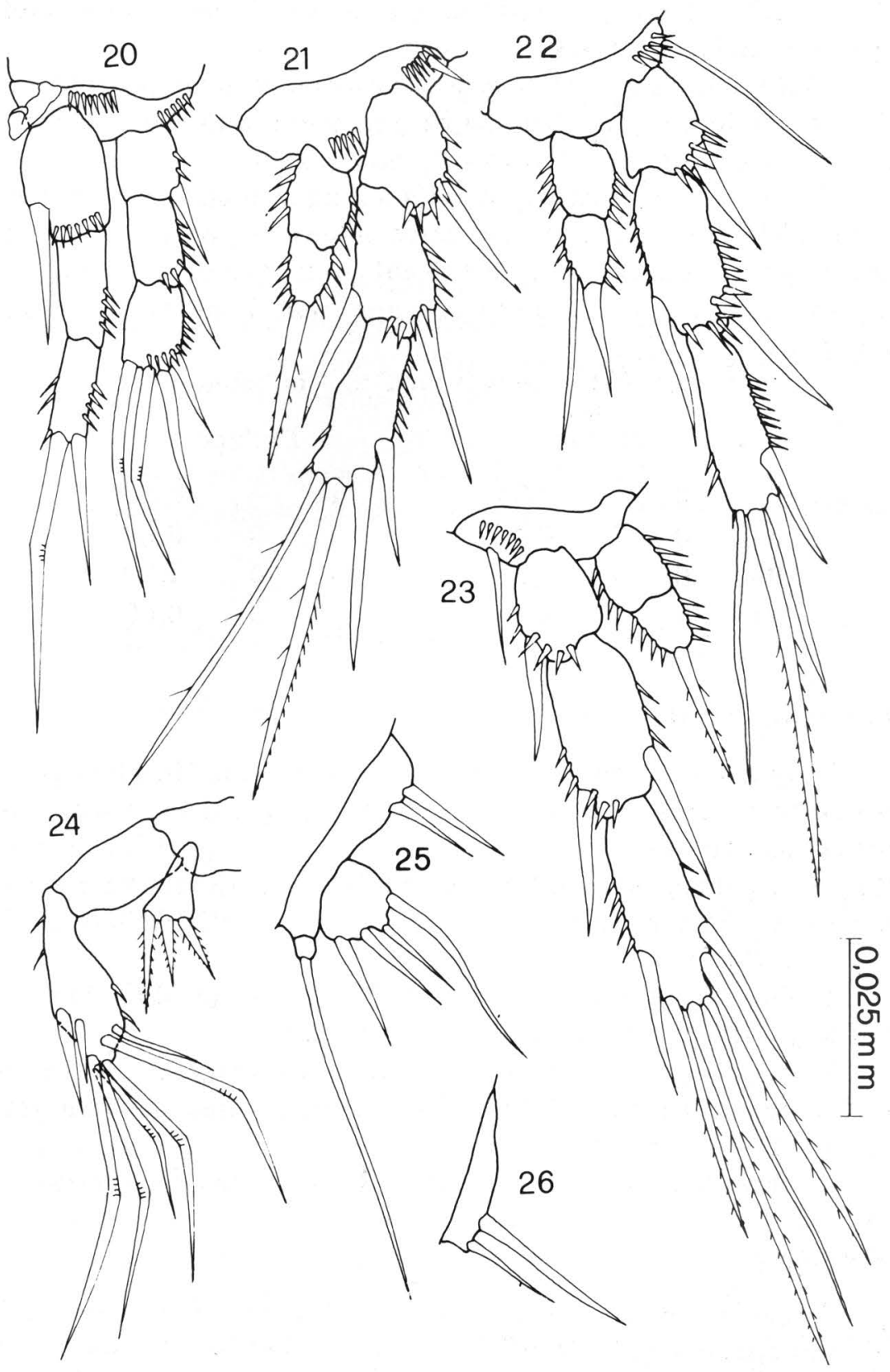

Figs. 20-26 - Nitocrella beatricis n. sp. 20,21,22,23,24,25,26: paratype §. 20, P1; 21, P2; 22, P3; 23, P4; 24, antenna; 25, P5; 26, P6. 
Derivatio nominis

The new species is dedicated to Mrs. Beatrice Deriu, as a friendly acknowledgement of the help she gave to V. Cottarelli for some sampling, and the hospitality she offered him in Sardinia.

\section{Affinities}

$N$. beatricis $\mathrm{n}$. sp. fits well with the species group vasconica Petkovski, 1976, to which all the species showing the last segment of exopod P4 with six setae belong. In this group, $N$. vasconica Chappuis, 1937, found in Spain, seems to have some affinities with the new species.

We notice moreover that $N$. beatricis $\mathrm{n}$. sp. is the first species belonging to vasconica group known in the Sardinian fauna until now.

Fam. CANTHOCAMPTIDAE Sars, 1906; Monard, 1927; Lang 1948

Gen. Ceuthonectes Chappuis, 1923

Ceuthonectes pescei Cottarelli \& Saporito, 1985

\section{Material}

1 \& adult, M. Cobolli, V. Cottarelli, E. De Matthaeis legg., 1.VI.1992 collected with the same method and in the same station of the "Bue Marino" cave indicated before.

\section{Remarks}

The specimen from the "Bue Marino" cave certainly belongs to Ceuthonectes pescei. Up to now this species was only known from its type locality: a well not so far from the «Bue Marino" cave (Cottarelli \& Saporito, 1985). This is the second male specimen ever found. We provide therefore pictures of the P2 endopod (Fig. 27), P3 (Fig. 28), P4 (Fig. 30), P5 (Fig. 31), P6 (Fig. 33), anal operculum (Fig. 32), maxilla (Fig. 29). This last appendix is different from the original description because the second endite is armed with three setae instead of two. 

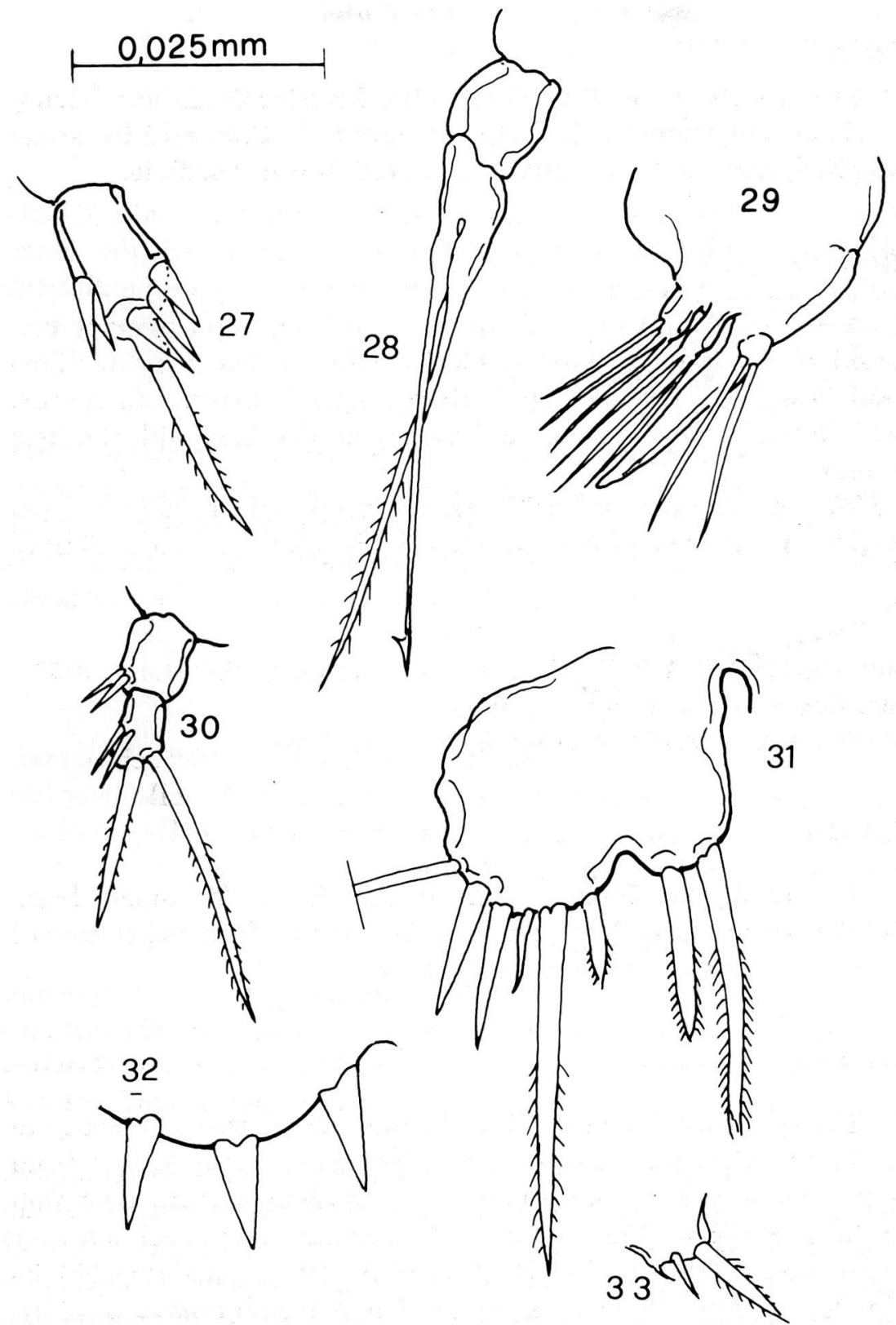

Figs. 27-33 - Ceuthonectes pescei, §. 27, P2 endopod; 28, P3 endopod; 29, maxilla; 30, P4 endopod; 31, P5; 32, anal operculum; 33, P6. 
Gen. Elaphoidella sensu Apostolov, 1985

Elaphoidella janas n. sp.

\section{Material}

5 ㅇ, (2 ovigerous), 3 \& 8,1 female copepodite, M. Cobolli, V. Cottarelli, E. De Matthaeis legg., 1.VI.1992, collected with the same method and in the same station of the "Bue Marino" cave indicated before.

\section{Types}

Holotype: a mature female, dissected and mounted on a slide labelled E. janas ht. Paratypes: the remaining specimens, mounted on slides labelled $E$. janas pt., numbered from 1 to 7 . The material of the typical series is temporarily deposited at the "Dipartimento di Scienze Ambientali, Università della Tuscia», Viterbo (Cottarelli collection).

\section{Diagnosis}

An Elaphoidella of the gracilis group Apostolov, 1985, characterized, among other things, by the combination of the following features: ornamentation of P2 and P3 endopods and of anal operculum, shape and chaetotaxy of furcal rami.

\section{Description of the holotype}

Body somewhat slender, subcylindrical, posteriorly tapering, depigmented and without photoreceptors. Length, from the rostrum to the apex of the furcal rami, $0.693 \mathrm{~mm}$. Body with a row of spines on the ventral and distal margin of genital, postgenital and terminal somites.

Distal margins of the thoracic somites dorsally denticulated; the denticulation is also present along the distal margins of the abdominal somites. Anal somite (Fig. 34) with a transverse row of spines aligned ventrally at about half of the length; 3 - 4 spines inserted near the basis of each furcal ramus (Fig. 34); remaining ventral and dorsal ornamentation is shown in figures.

Anal operculum (Fig. 34): convex, with 18-20 «tubercles» aligned along the margin. Furcal rami (Fig. 34): cone-shaped and elongated (length/width ratio: 2,2); outer margin with a seta and three spines; 


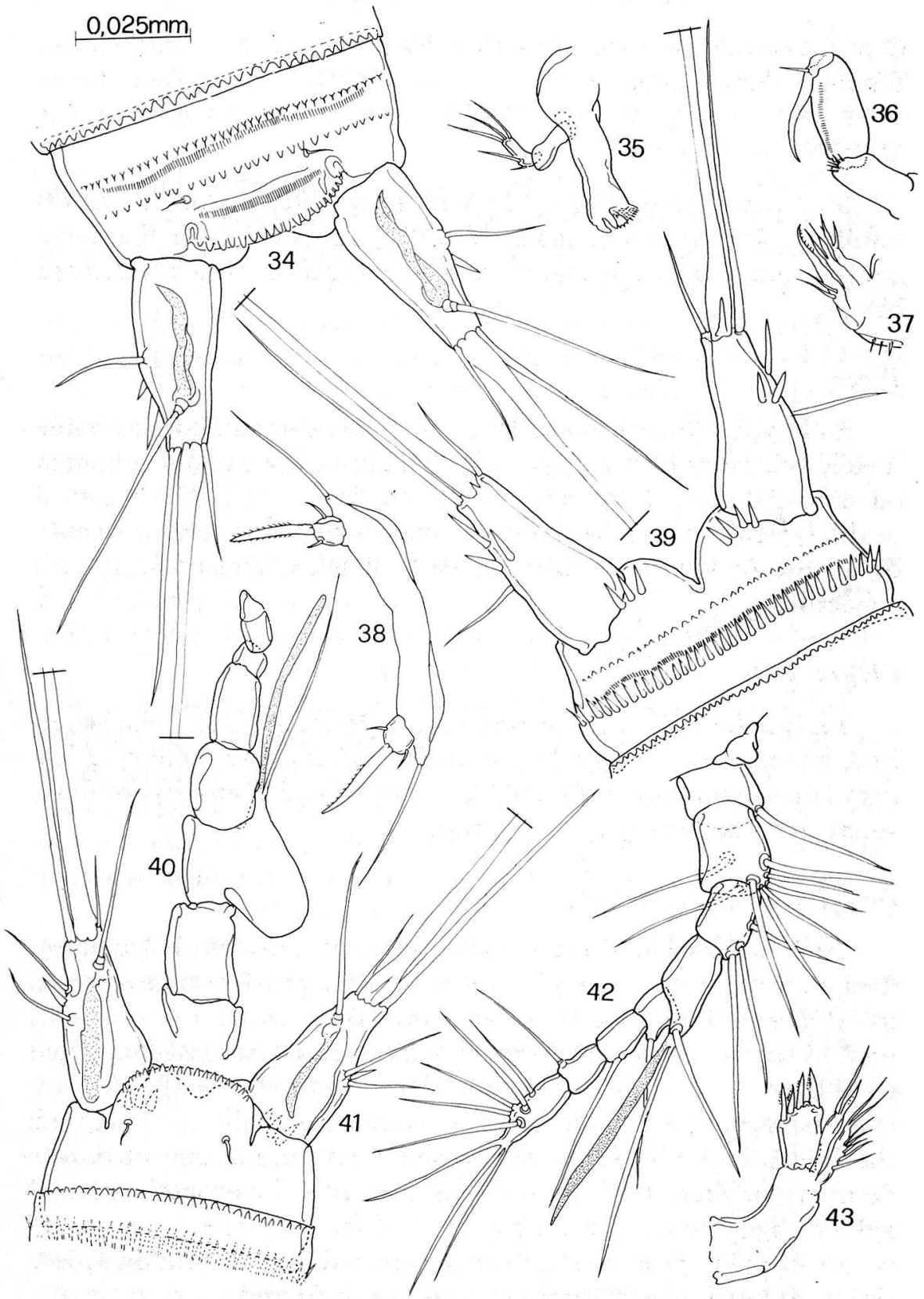

Figs. 34-43 - Elaphoidella janas n. sp. 34, 35, 36, 37, 39, 42, 43: holotype $9.38,40,41$ : paratype 8.34 , last somite, anal operculum and caudal rami, dorsal view; 35 , mandible; 36, maxilliped; 37, maxilla; 38, P5; 39, last somite and caudal rami, ventral view; 40 , antennula; 41 , last somite, anal operculum and caudal rami, dorsal view; 42 , antennule; 43, maxillule. 
three apical setae: the medial seta is the longest, the outer seta is three times as long as the corresponding inner one; a last dorsal composite seta, longer than the furcal ramus, is inserted near a chitinous protrusion.

Antennule (Fig. 42): eight-segmented; aesthete on fourth segment not much exceeding the tip of the distal segment.

Antenna: allobasipod unarmed; one-segmented exopod with two distal and two subdistal spinulose setae.

Mandible (Fig. 35): praecoxa with a bi-dentate pars incisiva: twosegmented palp: the first article unarmed, the second one has three distal setae, a proximal seta and a spinula.

Maxillule (Fig. 43): arthrite of the praecoxa with four distal spines; coxa with two setae; basipod with two distal and five lateral setae.

Maxilla (Fig. 37): syncoxa with two endites, bringing two setae each one; endopod represented by two setae.

Maxilliped (Fig. 36): basipod with a distal row of spinules; first article of the endopod with a line of setulae; second article with a strong, recurved thorn and a little spine.

P1 (Fig. 52): both rami are three-segmented; endopod longer than the corresponding exopod; the first segment of the endopod is as long as the first two segments of the corresponding exopod, with a seta on the inner margin; second segment also armed with a seta; third segment with three setae, the longest one is geniculated. Second article of the exopod with a strong inner seta; third segment armed with two spinulose and two geniculate setae.

P2 (Fig. 50): endopod two-segmented; first segment with a thin seta; the second one has two inner-lateral and two apical setae. Third article of the exopod with five setae.

P3 (Fig. 45): endopod two-segmented, the first one unarmed, the second one with three distal setae. Distal segment of the exopod with six setae.

P4 (Fig. 44): endopod two-segmented; first article unarmed, the second with three apical setae. Distal article of the exopod with six setae.

P5 (Fig. 46): exopod approximately quadrangular and provided with a strong distal spinulose seta and two subdistal short setae; the outer margin with a spinule. The inner lobe of the baseoendopod has three long spinulose setae. 


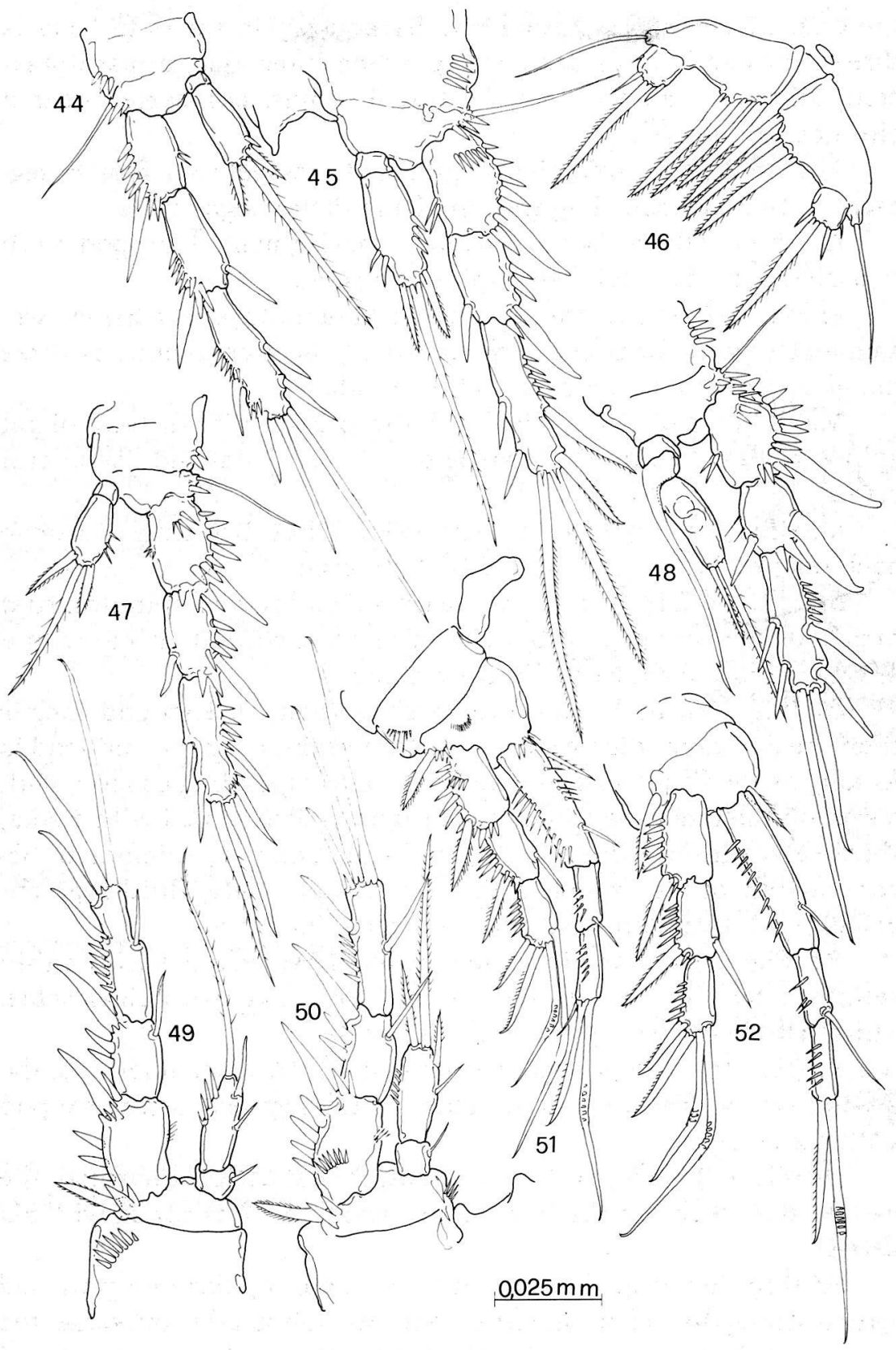

Figs. 44-52 - Elaphoidella janas n. sp. 44,45,46,50,52: holotype $q ; 47,48,49,51$ : paratype o. 44, P4; 45, P3; 46, P5; 47, P4; 48, P3; 49, P2; 50, P2; 51, P1; 52, P1. 
The setal formula of the legs from 1 to 4 is listed below:

\begin{tabular}{lllllcr} 
& \multicolumn{3}{c}{ Exopod } & \multicolumn{3}{c}{ Endopod } \\
P1 & 0 & 1 & $1,2,1$ & 1 & 1 & $1,1,1$ \\
P2 & 0 & 1 & $1,2,2$ & - & 1 & $2,2,0$ \\
P3 & 0 & 1 & $2,2,2$ & - & 0 & $1,1,1$ \\
P4 & 0 & 1 & $2,2,2$ & - & 0 & $1,1,1$
\end{tabular}

Description of the male

Length, measured in the same way as in the female, $0.664 \mathrm{~mm}$. Rostrum, A2, mouthparts, maxillipeds, body ornamentation and anal operculum as in female. The chaetotaxy and the shape of P1 (Fig. 51), P2 - P4 exopods and furcal rami are also similar to the female's one, apart from some little differences regarding the size and length of setae and spines.

Antennule (Fig. 40): seven-segmented and haplocer; aesthete on third segment a little longer than the tip of the distal segment.

P2 (Fig. 49): endopod two-segmented; second article with three setae.

P3 (Fig. 48): three-segmented endopod; first article unarmed; medial segment with a long, lanceolate apophysis; distal segment with two setae of different length.

P4 (Fig. 47): endopod biarticulated, with the same ornamentation as in the female but shorter.

P5 (Fig. 38): baseoendopod bare; exopod little, suboval, with a strong apical seta and two small ones.

Anal operculum and furcal rami (Fig. 41).

\section{Etimology}

The word janas refers to «Domus de janas», in the Sardinian language a common name of the caves, which means "sorceress's house».

\section{Variability}

The features considered above appear to be constant in all the specimens of the typical series. Females are always bigger than males. 


\section{Affinities}

E. janas n. sp. belongs to gracilis group of Elaphoidella as defined by Apostolov, 1985. Within this group, the new species resembles both E. damianae Kiefer, 1967, from Rumanian groundwaters, and $E$. proserpina Chappuis 1934. However, the new species resembles more E. federicae Pesce \& Galassi, 1988, from the phreatic waters of Corsica; the armature of the exopods P1, P3, P4, P5 and $\mathrm{P} 2$ in both sexes are shared with these species. E. janas n. sp. differs from the former species in the shape and ornamentation of the body somites, the anal operculum, the caudal rami and the P2 endopod in both sexes, armed with four and three apical setae respectively, instead of three and two setae. The mouthparts cannot be compared, because they are undescribed in E. federicae. Finally, it may be interesting to observe that the new species has very few affinities with E. nuragica Pesce \& Galassi, 1986, 1988, the only Elaphoidella described until now from groundwater of Sardinia.

Fam. PARASTENOCARIDIDAE Chappuis, 1933

Gen. Parastenocaris Kessler, 1913

Parastenocaris triphyda n. sp.

\section{Material}

6 of and 4 \& $8 \mathrm{~V}$. Cottarelli leg., 1.VI.1992 collected with the same method, in the same station of the "Bue Marino" cave before indicated.

\section{Types}

Holotype: $1 \delta$, completely dissected and mounted on a slide labelled P. triphyda ht. Paratypes: all the other specimens, mounted on slides labelled $P$. triphyda pt., numbered from 1 to 9 .

\section{Diagnosis}

A Parastenocaris of the minuta group Lang, 1948, mainly characterized by the combination of the following features: peculiar morphology and ornamentation of P3 legs, P4 endopods of the males and furcal rami of both sexes. 


\section{Description of the holotype}

Body cilindrical and lengthened, depigmented; no photoreceptors. Length, from the rostrum to the apex of the furcal rami, $0.330 \mathrm{~mm}$.

The ventral surface of the last abdominal somite with two groups of spinules near the median line (Fig. 67).

Anal operculum (Fig. 67): with semicircular distal margin.

Caudal rami (Fig. 67): much longer than the last abdominal somite, approximately cylindrical, very long and slender: length/width ratio $=7.2$. Ornamentation represented by three apical setae, three spinules ventrally inserted; three little setae originate sub-apically from the outer lateral margin; a last composed seta is inserted dorsally.

Rostrum (Fig. 68): little and triangular, with two sensillae. Antennule (Fig. 68): seven-segmented; the first segment unarmed, the second one with a proximal plumose seta and four distal setae; third segment with four distal setae too; fourth segment, not very enlarged, armed with two long and a short setae and a big aesthete; fifth segment with a single distal seta; the sixth segment, prolonged distally into a sharpened aphophysis, is moreover unarmed; the seventh segment brings seven setae and an apical aesthete.

Antenna (Fig. 63): one-segmented little exopod with an apical spinulose seta; allobasipod unarmed; distal segment of the endopod with five setae, one modified and two geniculate ones and a spine, distally inserted.

Mandible (Fig. 62): one-segmented palp with two setae.

Maxillule (Fig. 61): difficult to observe; the praecoxal arthrite with three distal spines; the coxa is armed with a short distal seta; basipod with two distal setae.

Maxilla (Fig. 64): syncoxa with an endite bringing a seta; basis prolonged into a distally curved tip; endopod represented by a little tubercle with only one seta.

Maxilliped (Fig. 57): lenghtened; second segment with a spinulose thorn.

P1 (Fig. 53): exopod three-segmented, shorter than the endopod; distal segment with a subapical outer seta and three apical ones, two of which are geniculate. Endopod two-segmented: the first segment with two groups of lateral spinules; the second segment with two lateral spinules and two apical setae; the longest one is geniculate. 


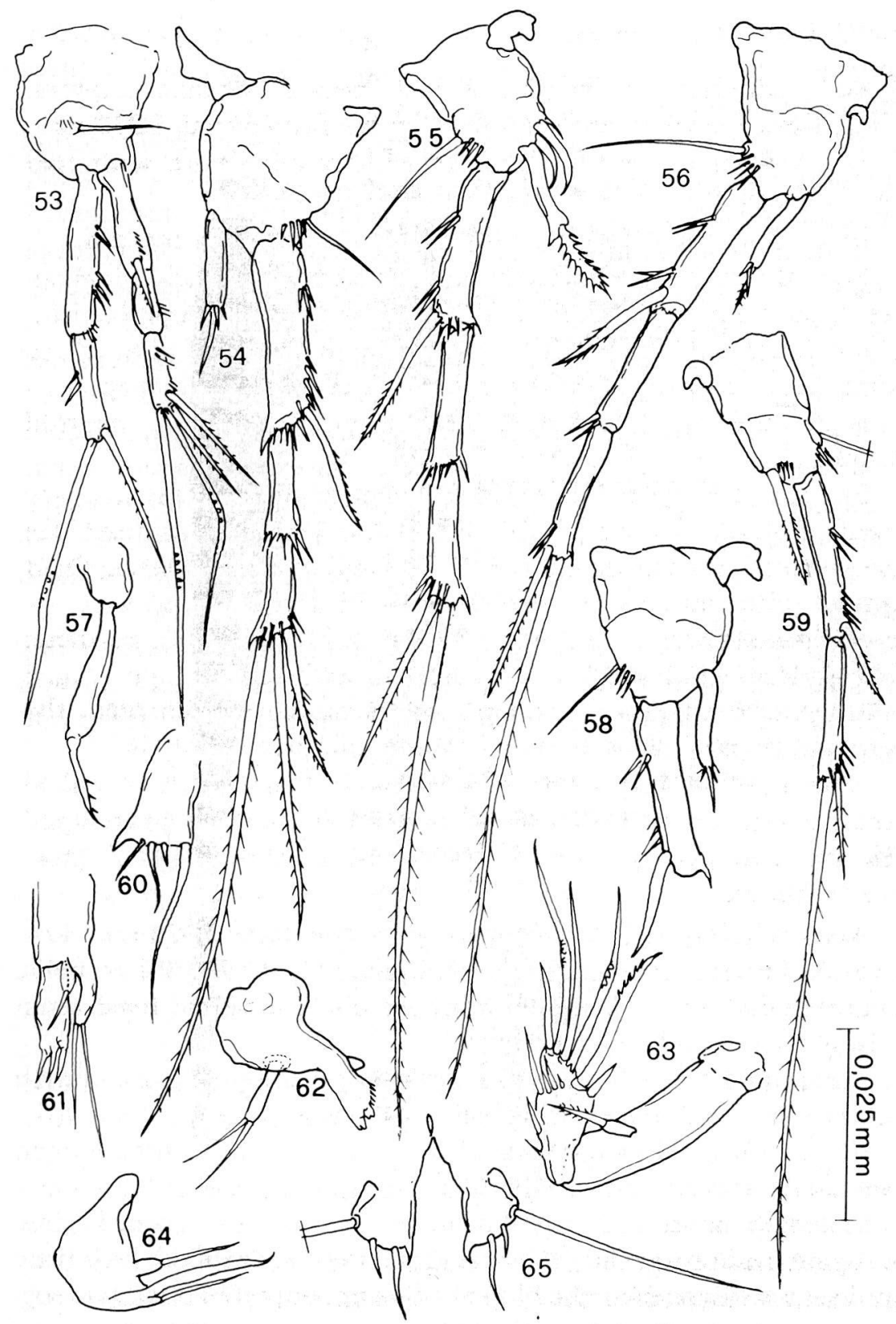

Figs. 53-65 - Parastenocaris triphyda n. sp. 53,54,55,57,60,62,63,64: holotype 8 ; 56,58,59,65: paratype $+.53, \mathrm{P} 1 ; 54, \mathrm{P} 2 ; 55, \mathrm{P} 4 ; 56, \mathrm{P} 4 ; 57$, maxilliped; 58 , P2 endopod; 59, P3; 60, P5; 61, maxillule; 62, mandible; 63, antenna; 64, maxilla; 65 , P5. 
P2 (Fig. 54): exopod three segmented, ornamentation is shown in figure; endopod represented by a little cylindrical segment with three apical spinules and one seta.

P3 (Fig. 66): quite long and slender; basis with a long external seta followed by a series of spinules; endopod reduced to a stick-like appendix. The first segment of the exopod, slender and slightly curved, has a tubercle on the proximal side of the inner margin; two groups of spiniform setae are inserted on the outer margin. The segment ends into a long spoon-like and very sharpened apophysis. The second exopodial segment has a peculiar morphology: it is represented by a narrow and sinuous appendix, distally ending in three tips.

P4 (Fig. 55): exopod three segmented, chaetotaxy shown in figure. The endopod, as long as the first segment of the exopod, is represented by a segment with a sharpened extroflession coming from the distal outer corner; the segment continues into a narrow, spinulate lamina. Near the basis of the endopod two strong curved thorns and a spinula are inserted.

P5 (Fig. 60): represented by a quite rectangular plate with a long and slender seta on the distal outer corner, a short spinula and two setae on the distal margin; the distal inner corner is prolonged into a slightly curved tip.

\section{Description of the female}

Length, measured in the same way of the male: $0.322 \mathrm{~mm}$. Rostrum, A2, mouth appendages, maxillipeds, P1, P2 and P4 exopods, ornamentation of the last abdominal somite and furcal rami, as in the male.

Antennule (Fig. 69): seven-segmented; aesthete of the fourth segment smaller than in the male.

P2 (Fig. 58): endopod similar to the male's one, but a little longer, with an addictional apical spinula.

P3 (Fig. 59): endopod represented by a narrow and sharpened spinulate segment, shorter than the first segment of the exopod; four little spinules are aligned near the base of this appendix. Exopod two segmented, ornamentation as in figure.

P4 (Fig. 56): cylindrical endopod, shorter than the first segment of the corresponding exopod, armed with two distal spinules and a small seta. 


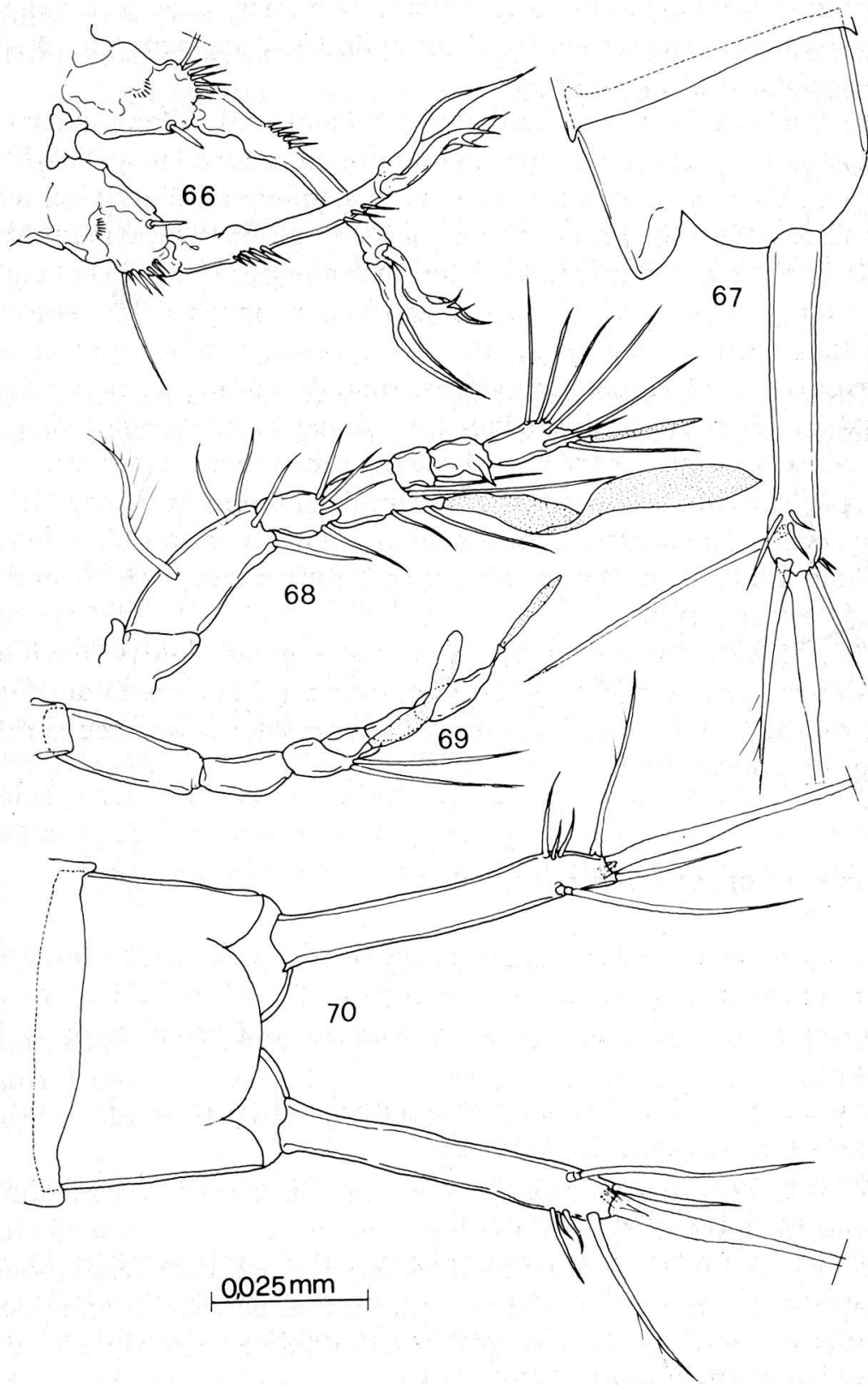

Figs. 66-70 - Parastenocaris triphyda n. sp. 66,67,68,70: holotype $\delta ; 69$ : paratype 9 . 66 , P3; 67, last somite and caudal rami, lateral view; 68 , antennule, 69 , antennule; 70 , last somite, anal operculum and caudal rami, dorsal view. 
P5 (Fig. 65): ornamentation represented by a long seta which originates from the distal outer corner; distal margin provided with two setae; distal inner corner extended into a curved tip.

\section{Etimology}

The latine adjective triphyda is referred to the particular shape of the second exopod-segment of the male's P3.

\section{Variability}

The features considered above appear to be constant in all the specimens of the typical series. Females are always smaller than males.

\section{Affinities}

P. triphyda n. sp., because of the construction and ornamentation of both the endopod and basis of P4 in male, well fits the minutagroup of species sensu Lang, 1948. Within this group the new species resembles P. trinacriae Pesce et al., 1988, from Sicily, but resembles even more P. nertensis Rouch 1990, from the Nert brook underflow of the Pyrénées (France). Hovewer, P. triphyda n. sp., is easily recognizable from the above species and from all the other species of the group, because of the characteristic morphology of P3 in males and the considerable length of the furcal rami in both sexes.

\section{REMARKS}

Sardinia is covered for about $1 / 10$ of its surface by calcareous formations (2250 square $\mathrm{km}$ ): some are typical paleo-Karst formations from the Cambrian but mostly from the Mesozoic period (From Cassola, 1978).

The "Bue Marino» cave is a calcareous cave from medium Jurassic in Orosei gulf, with three distinct entrances; it extends for about 4,5 km with two main branches: a northern fossil one, equipped for turist visits, and a southern one, active, not equipped for tourists, which can be crossed partly on foot and partly with the aid of row-boats (Casale, 1972). The cave is well known by the biospeleologists because it has been explored several times: the first 
faunistic researches were carried out by Saverio Patrizi in 1955 (Cassola, 1978). It is also well known because it is inhabitated by many terrestrial troglobionts of great interest; and it is also one of the few caves in Sardinia where acquatic fauna has been collected (Lindberg, 1956; Stella, 1957). Cassola (1978) and Casale (1972) provide a complete list of the terrestrial and acquatic taxa known for the "Bue Marino» cave. The most interesting elements of acquatic fauna are two Ciclopoids: Speocyclops sardus Lindberg, 1956, an endemic stygobiont, and Dyacyclops crassicaudis cosana Stella \& Salvatori, 1954, a stygophile or eustygophile. As far as Harpacticoids, Lindberg (1956) mentions three stygoxene species from brackish or marine waters, and Stella (1957) mentions marine Harpacticoids sampled at the entrance of the cave, in marine water.

Actually, periodical researches of the Crustacean fauna of the subterranean waters of Sardinia (more recently concerning the minor Islands as well), have been carried out for more than twenty years by the senior Author. This effort has allowed us to get many results which are particularly interesting for their taxonomical and biogeographical aspects.

At the beginning, these researches have dealt with the "superficial» water-bearing stratum, expecially the hyporheic habitats. Then, it became necessary to explore the "deep» water-bearing stratum, sampling in wells and caves. The first results, some of them still unpublished (Cottarelli, in litteris), seem to confirm that «the interstitial habitats, previously considered as homogeneus compared to epigean biotopes, are now recognized as heterogeneous, mainly because of the influence hydrology exerts on the physical, chemical and biological structure of the system» (Dole-Olivier et al., 1993).

Considering only the Sardinian fauna (data concerning Corsica are still insufficient), it can be observed that some genera (Nitocrella, Parastenocaris, Elaphoidella), have been found both in superficial and deep strata. Nevertheless, while the only Nitocrella ever sampled in all these habitats are $N$. beatricis $\mathrm{n}$. sp. and $N$. stammeri Chappuis, 1938, the genera Elaphoidella and Parastenocaris are represented by different species. P. ima Cottarelli, 1989 and P. triphy$d a$ n. sp. are specific of deep waters, all the other Parastenocaris known in Sardinia have never been found in wells or in cave (Cottarelli, unpublished data).

Finally, Ceuthonectes, present in Sardinia with C. pescei, seems to be confined to the wells and to the subterranean cave waters. 
Similar considerations can be applied to other groups of Crustaceans. An example is provided by the Syncarida, present in Sardinia with the species Sardobathynella cottarellii Serban, 1973, and two undescribed species of Exobathynella, found in hyporheic waters and in artesian strata, and Meridiobathynella which instead seems typical of wells.

Besides the faunistical, taxonomical and ecological interest, the distribution of $N$. beatricis $n$. sp., is of zoogeographical interest; this species, present in Sardinia and Corsica, could be one of the few endemic Corsica-Sardinia elements which are in counterposition with "the high discordance index between the two islands» (Cassola, 1978). E. janas n. sp. which has a great affinity with a corsican congeneric species, seems to be another example of this kind. Finally, as far as Parastenocaris is concerned, many of the Sardinian species, including the species described here, show affinities with pyrenaic and provençal ones. This genus, too, could belong to those taxa present in Sardinia, Southern France, Maritime Alps and Eastern Spain, but absent in Corsica for various reasons (following submersions, quaternarian ice-ages, the «solco di Terranova» effect).

\section{ACKNOWLEDGEMENTS}

We thank Professors Marina Cobolli, Elvira De Matthaeis, Augusto Vigna Taglianti from «Università degli Studi di Roma La Sapienza» and Professor Achille Casale from «Università degli Studi di Sassari», for partecipating to the researches and contributing to the sampling. We are also grateful to A. Vigna Taglianti and A. Casale for exchanging useful opinions and informations. Particular thanks are due to the Municipality and to the speleologists of Dorgali who kindly offered us the row-boats and part of the speleologic equipment.

\section{REFERENCES}

APOSTOLOV, A., 1985. Etude sur quelques Copépodes Harpacticoides du genre Elaphoidella Chappuis, 1929 de Bulgarie avec une révision du genre. Acta. Mus. Maced. Sci. nat. Skopje. 17 (6/14): 133-160.

CASALE, A. 1972. Visione d'insieme del complesso ecologico e faunistico della grotta del Bue Marino (Cala Gonone, Dorgali, NU). Boll. Soc. Sarda. Sc. Nat. 6 (10): 8-28.

CASSOLA, F. 1978. Il popolamento cavernicolo della Sardegna. Lav. Soc. it. Biogeogr. 7: 615-755.

CHAPPUIS, P.A. 1934. Ostalpine Höhlencopepoden. Bul. Soc. Sti. Cluj. 8: 211-217.

CHAPPUIS, P.A. 1937. Subterrane Harpacticoiden aus Nord-Spanien. Bul. Soc. Sti. Cluj. 8: 556-571.

CHAPPUIS, P.A. 1938. Subterrane Harpacticoiden aus Süd-Italien. Bul. Soc. Sti. Cluj. 9: 153-181.

COTTARELLI, V. 1989. Un nuovo Arpacticoide freatobio dell'Isola della Maddalena (Sardegna): Parastenocaris ima n. sp. Ann. Mus. Civ. St. nat. Genova. 87: 285-296. 
COTTARELLI, V. and P.E. SAPORITO. 1985. Ceuthonectes pescei n. sp., Arpacticoide freatobio di Sardegna (Crust. Cop.). Fragm. Entomol. 18 (1): 11-17.

DOLE-OLIVIER, M.J., M. CREUZE' DES CHATELLIERS, and P. MARMONIER. 1993. Repeated gradients in subterranean landscape. Example of the stygofauna in the alluvial floodplan of the Rhone River (France). Arch. Hydrobiol. 127 (4): 451-471.

GALASSI D.P. and L. PESCE. 1987. New localities of Elaphoidella nuragica Pesce \& Galassi, with a description of the female (Cop. Harpact.: Canthocamptidae). Boll. Mus. civ. St. nat. Verona. 14: 311-314,

KIEFER F. 1967. Copepoda. In: J. Illíes, ed., Limnofauna Europea, Stuttgart: 173-174.

LANG, K. 1948. Monographie der Harpacticiden. Nordiska Bokhandeln, Stockholm. $1-1682$.

LINDBERG, K. 1956. Cyclopides (Crustacés Copepodés) de la Sardaigne. Mem. Soc. Entomol. Ital. 35: 71-79.

PESCE, L. and D.P. GALASSI. 1986. A new species of Elaphoidella from groundwater of Sardinia, and first record of Elaphoidella cvetkae Petkovski from Italy (Crustacea: Harpacticoida). Bull. Zool. Mus. Univ. Amsterdam. 10 (27): 221-225.

PESCE, L. and D.P. GALASSI. 1988. Elaphoidella federicae spec. nov., a new harpacticoid copepod from phreatic waters of Corsica (Crust. Harpact.: Canthocamptidae). Stygol. 4 (3): 262-266.

PESCE, L., D.P. GALASSI and V. COTTARELLI. 1988. First representative of the family Parastenocarididae from Sicily (Italy), and description of two new species of Parastenocaris Kessler (Crustacea Copepoda: Harpacticoida). Bull. Zool. Mus. Univ. Amsterdam. 11 (16): 137-142.

PETKOVSKI, T.K., 1976. Drei neue Nitocrella-Arten von Cuba, zugleich eine Revision des Genus Nitocrella Chappuis (s. restr.) (Crustacea, Copepoda, Ameiridae). Acta Mus. Mac. Sc. nat., 15 (1): 1-26.

ROUCH, R. 1990. Deux nouvelles Parastenocaris (Copépodes, Harpacticoides) des Pyrénées. Annls. Limnol. 26 (1): 19-28.

STELLA, E. 1957. Il plancton delle acque di una grotta della Sardegna. Boll. Zool. 24 (1): 39-44.

STELLA, E., F.B. SALVATORI 1954. La fauna acquatica della grotta di "punta degli Stretti» (Monte Argentario). Arch. Zool. ital. Napoli. 38: 441-483.

VIGNA TAGLIANTI, A., V. COTTARELLI and R. ARGANO. 1969. Messa a punto di metodiche per la raccolta della Fauna interstiziale e freatica. Arch. Bot. Biogeogr. Ital. 45 (4): $375-380$. 